\title{
Fragmented boundary zones between theory and practice in preschool teacher education in Sweden
}

\author{
Jan Gustafsson Nyckel, Rolf Lander and Per-Olof Thång
}

\begin{abstract}
Research dealing with preschool teacher education has been, for a long time, critical of a binary divide between theory and practice. Based on that issue, this study investigates a preschool teacher education programme in Sweden. It focusses on reflection upon theory and practice as an affordance offered to students in studies and work. The study used a questionnaire with two different groups: campus students following the regular programme and students who were nurses already working at preschools. Analysis shows a fragmented education where the groups faced different problems, but also that neither of them could connect reflections on theory and practice at the workplace to their own deep learning approaches in either studies or working matters. How the students experienced affordances depended on their educational skills and knowledge, and the programme relied mostly on individual reflection as the solution to the binary divide. This reliance seemed to work better for campus students, who were challenged by the new environmental affordances. The students in the field-based programme were very close to the preschools' pedagogical micro-practice, which limited the possibility for critical reflection on theory and practice and its contextual conditions, especially for students who were nurses. Workplace routines seem to structure the students' learning instead.
\end{abstract}

Keywords: affordance; learning approach; preschool teacher education; study approach; theory and practice

Received 9 April 2020; revised version received 22 November 2020; accepted 23 November 2020. Corresponding author: Jan Gustafsson Nyckel, University West, Sweden (jan.gustafsson-nyckel@hv.se).

\section{Introduction}

In all kinds of professional education there is often said to be a binary divide between theory and practice, and most certainly this is so within teacher education (Sjølie, 2014; Zeichner, 2010), which has been criticised for more than a hundred years, from Dewey (1904) to, for example, Kim and Kim (2017). This article investigates ways to handle the disconnect between campus and field-based education in preschool teacher education programmes and evaluates such a Swedish approach. 
Zeichner (2007) points out that the relationship between campus and field-based teacher education has a strong impact on the students' opportunities for learning. Traditionally this has been handled by assuming that theory is applied to the practice of the field-based education (Zeichner, 2010). However, according to Zeichner, this model creates problems for students' understanding of the relation between theory and practice. The field-based education therefore ought to constitute a more productive environment for professional learning. According to Klien et al. (2013, p. 28), 'a hybrid or a third space' is needed to overcome the cultural cleavage, a space where 'roles and responsibilities for faculty teachers, and community members are redefined while the knowledge base for teaching is restructured'. Development work with hybrid models is carried out all over the world (Zeichner, 2010).

This article focuses on a hybrid programme in Swedish preschool teacher education and aims to see if it managed to address the cleavage or if it worked any differently from a regular campus programme. Based on a governmental commission (SOU 1999:63, p. 76), it became mandatory from 2001 for all teacher education programmes to develop such hybrid programmes. In 2020, thirteen Swedish universities organised parts of their preschool teacher education as hybrid models.

We investigate two different groups of students at one of Sweden's largest preschool teacher education programmes. One group was studying within a campus model, with the field-based education as a vital part. The other group studied within a hybrid model, where the students worked and completed study assignments four days a week at their place of work and studied one day on campus. The aim is to investigate how students participating in each model were invited to see and reflect upon affordances in the practice, seen through theoretical lenses, and what effects this had on their professional development. The same questionnaire was given to the two groups after they had been studying for three years. After a description of the preschool teacher education programme in Sweden, we provide a brief research review on the relation between theory and practice in teacher education, which is followed by a comparison of the hybrid programme investigated to others of a similar kind, a presentation of our theoretical assumptions, the student groups that were investigated, and our empirical analysis.

The article concludes with a discussion in which we point out that the two educational environments, the campus and field-based education (workplace) afford two different ways of reflecting on theory and practice. We also highlight that neither of the student groups could connect reflections on theory and practice at the workplace to students' own deep learning approaches in either studies or working matters. The study followed the Swedish Research Council's ethical principles (2015) on informed consent and anonymity. 


\section{Preschool teacher education in Sweden}

The Swedish preschool teacher education programme started during the mid-1960s as a two-year vocational school which was not part of any university. In 1977, it was integrated into the higher education system, and the programme took on a traditional academic structure with no obvious ties to preschool practice. However, the goals of both academic and vocational educational skills remained.

An evaluation judged that the practical pedagogical training did not achieve an acceptable level of competence (Swedish Council for Higher Education, 1996). This prompted a critical discussion about professionalism in which the solution implemented was an even stronger academic structure and more theoretical content, but supported by teaching of didactics (Englund, 1996). ${ }^{1}$

\section{Previous research on theory and practice in teacher education}

The transfer of knowledge between campus- and field-based teacher education is seen by many as too weak (Allen \& Wright, 2014; Karlsson Lohmander, 2015; Korthagen, 2010; Zeichner, 2010). Korthagen (2010) also pointed out that the propositional theory learned on campus is not felt to be helpful by students. As new teachers, they are involved in a socialisation process at schools and are thereby introduced to institutionalised patterns of behaviour not easy to change for individuals. Han, Blank, and Berson (2017), Kim and Kim (2017), and others, have confirmed this.

Bell (2004) described a more than 20-year-old field-based preschool teacher education programme in New Zealand, which consists of three years of full-time studies and is conducted at 13 rather small teaching centres with local lecturers. The students had long-term experience from earlier work at preschools. One day a week, the students had theoretical, teacher-led instruction and one day individual, theoretical studies. The other three days of the week, the students worked at the preschools where they have their employment. Three weeks each year, they also practiced at a preschool other than their own. This arrangement made it possible for students to make use of theories in authentic preschool practice and allowed formal theory to be contextualised.

Beavers, Orange, and Kirkwood (2017) reported a trial with ten preschool teachers-to-be who, in seven weeks of practicum, took part in intense reflections upon practical situations, and showed considerable progress in challenging their own preconceived notions and typical practices. The trial included training in four different roles (lead teacher, assistant teacher, administrator, and assistant administrator), and a constant cycle of supervised planning, implementing,

\footnotetext{
${ }^{1}$ Preschool teacher education in Sweden is a 3.5-year programme at the bachelor level. During the programme, students complete a total of 20 weeks of field-based education (practice) and you can study to be a preschool teacher at 13 universities in Sweden.
} 
assessing, and reflecting daily, weekly, and over the full summer programme. Daily semi-structured group reflections lasted for 45-60 minutes and were supported by students observing each other. Weekly and final reflections were in the form of individual diaries. However, a quantitative test of critical thinking skills before and after showed no change. Beavers et al. suspected that seven weeks of training was not enough for that.

According to Eriksson (2009), it is necessary to define the character of student teachers' work experiences, and this demands a strong partnership between their campus-based and field-based education, including personal relationships between students and their educators. Students are taken care of by mentors ${ }^{2}$ at their workplaces, but Franke and Dahlgren (1996) showed that mentors are reluctant to develop a strong relationship with student teachers. Karlsson Lohmander (2015) also suggested that another organisation of knowledge production within the programme for preschool teacher education is necessary. According to Lenz Taguchi (2010), the preschool teacher education programme must be organised through a mix of learning environments and spaces, which opens for a variety of knowledge production and student experience.

\section{Three hybrid models: the reflexive practice, workplace learning, and boundary crossing}

Based on the problems described above, there has been a movement towards changing teacher education and rethinking the relationship between theory and practice. Three theoretical models are common: reflexive practice, workplace learning, and boundary crossing.

Reflexive practice was attempted with a so-called realistic approach, building on gestalt formation theory and reflection - on - action Schön (1983) launched a new epistemology centred on the concept of reflection, alluding to Dewey's (1988) thoughts regarding reflective practice. For Dewey, practical thinking is to take part in collective use of socio-cultural resources (language and artefacts) in order to recognise and frame problems and solutions. It is a 'perceptual awareness', says Korthagen (2010, p. 672), pointing to the Aristotelian concept of phronesis, a form of practical wisdom. We think that perceptual awareness is about affordance, a concept explained later in the text.

Still, reflective thinking on action is a good thing when socio-cultural resources are systematically and critically investigated, once again in light of the problems noted (Dewey, 1988). However, to reach the goal of reflective thinking, deep approaches to learning, which invite a search for meaning in tasks, are needed, especially when 'critical reflection' is defined as including a questioning of the validity of one's earlier thinking. A high level of this kind of reflection is relatively rare (Lundgren \& Poell, 2016). Beach (2000) stated that this kind of reflection has to overcome the basic problem that a reflexive mood is usually lacking, both in the teaching practices of schools and in university education. The other two approaches taken

\footnotetext{
2 The mentors are experienced preschool teachers at the students' workplace.
} 
up here - workplace learning and boundary crossing — both also seem to be firmly rooted in a trustful attitude to reflection-on-action. The difference lies in the organisation of tasks and learning.

A workplace learning approach strongly advises learning connected to everyday situations. Bell (2004) pointed out that professional competencies and learning cannot be acquired in formal education, only through authentic learning at work. However, learning through the workplace's everyday situations is a highly complex process, and there are no simple pedagogical solutions for learning to manage such a situation. Billett (2011) as well as Costley and Armsby (2007) described academia and workplaces as two different learning environments. Both the workplace and the university have their own aims and norms that structure content and activities and thereby create local orders. Billett (2011) argued that, as long as an individual is a student in a formal educational setting, environment will dominate over the workplace as a learning environment. This is also in line with Garraway (2010). Garraway suggested that exam models make it difficult for practice to serve as the basis for theoretical knowledge development, since there are fundamental 'differences between academic and work knowledge in terms of the context of learning and the structure of knowledge respectively, and hence the problem of transfer from the academic to the work world' (Garraway, 2010, p. 1).

Boundary crossing tries to develop the relationship between theory and practice by creating a boundary zone while students move between different educational settings (Akkerman \& Bakker, 2011). It is hoped that the zone provides opportunities for dialogue, meaning making, and knowledge production by integrating different activity systems. Learning in a boundary zone is attentive to both vertical and horizontal forms of learning. Vertical learning dominates theoretical and academic knowledge on campus. Horizontal forms of learning use every-day, practical knowledge.

Gutiérrez (2008) argued that horizontal learning that involves the student's reflection upon, and writing about his or her historical circumstances and ambitions of life will make them truly motivated. They should also participate in a range of practical activities outside school. Thereby multiple and sometimes conflicting activity systems will shape certain 'third spaces' within the programme, in which 'expansive learning' (Engeström \& Sannino, 2010) can develop through boundary crossing and networking. The thoughts about 'third spaces' have much in common with what Lenz Taguchi (2010) previously described as a mix of learning environments and spaces.

In summary, the models above show three different ways of addressing the binary divide between theory and practice in teacher education. The nursing model reported on in this article rests on an idea about authentic workplace learning that should afford integration of theory and practice. The model cannot be compared to the boundary zones or the workplace learning approach that Beavers et al. (2017) report on, or Korthagen's (2010) example of reflexive practice. Rather, it is more like Bell's (2004) example. 
In the programme involving nurses, the very authenticity of the workplace is meant to stimulate students to explore experiences in relation to theory together with mentors. However, there are no special arrangements for this to happen, like those existing in the hybrid models discussed above. The mentors were left alone with this task, and with no special training for it. As we shall see, this was not a good precondition for such reflection to be common. The other investigated model, a traditional preschool teacher education programme, is based on a transfer model.

The obvious trust in reflection-on-action can also be seen as complementing a trust in reflection-in-action, the second concept in Schön's typology (Schön, 1983). However, Erlandsson (2007) found the latter concept unrealistic for crowded schools and also theoretically building on a counterproductive cartesian division of bodily and mental abilities.

\section{Theoretical framework and design}

\section{Programme theory and mechanisms}

We refer to programme theory as one frame for our investigation. Programme theory is connected to evaluation, but also to a wider interest in social mechanisms in social sciences. Like Astbury and Leeuw (2010, p. 364), we think of programmes as 'embodiments of theory'. They are upheld by programme executors, but not seldom understood in a fragmented way that makes them into what Astbury and Leeuw call 'black boxes' that hide the real causal functioning of the programme. Programme theory is a way to unfold such boxes and analyse actual mechanisms.

Mechanism as a concept focuses on causal relations that connect intended activities to outcomes, that is, making the programme fail or succeed. Our study especially highlights problems with affordance and reflection.

Placing this model within a programme-theoretical framework aims at forming a causal chain of 'CMO-configurations' (Pawson \& Tilley, 1997). The acronym CMO stands for contexts-mechanisms - outcomes as a middle-range theory. In our investigation, contexts are the programmes' campus and workplace activities, and the primary mechanisms are experienced affordances and then learning approaches that students react with when confronting potential affordances from these activities. From a programme theory perspective, they should exist as intended and planned affordances, but are dependent on students' active curiosity and participation (Sadler \& Given, 2007). Outcomes are measured in terms of intellectual stimulation and learning resulting from their studies and contribute to a professional self-concept for their job. 


\section{Affordance}

For some time now affordance, as a theoretical concept, has been used within several fields to study how graduate students use the affordances of libraries (Sadler \& Given, 2007), teacher education (Berglund et al., 2019), and more generally for learning at workplaces (Billett, 2001), for example.

Affordances are about perceptual learning from the environment, and are always linked to specific contexts (Gibson, 2003a ${ }^{3}$ ). Students identify and use affordances for meaningful action (Withagen, Araújo \& de Poel, 2017). However, in education and practical training they need previously acquired skills and knowledge to be able to take full advantage of such actions. Then affordances change from a 'landscape', in which affordances are merely available, regardless of how they are perceived, into a 'field' that is 'calling for a certain way of action' (Withagen et al., p. 12, but the concepts of 'landscape' and 'field' are from Rietveld and Kiverstein, 2014).

We now turn to theoretical concepts that are directly measured in our questionnaire. Measures are nested pairs of general and specific factors, which will soon be explained. Factors can be seen in Figure 1, where the structural model is presented together with the standardised regression coefficients found. The hypothesised model contains two kinds of reflection and two kinds of outcome, mediated by two kinds of learning approaches. However, we had no particular hypotheses about specific relations between measures. All items belonging to the measurement models are included and presented in Tables 1-3 together with their standardised regression weights.

\section{$\underline{\text { Refl.TP }}$}

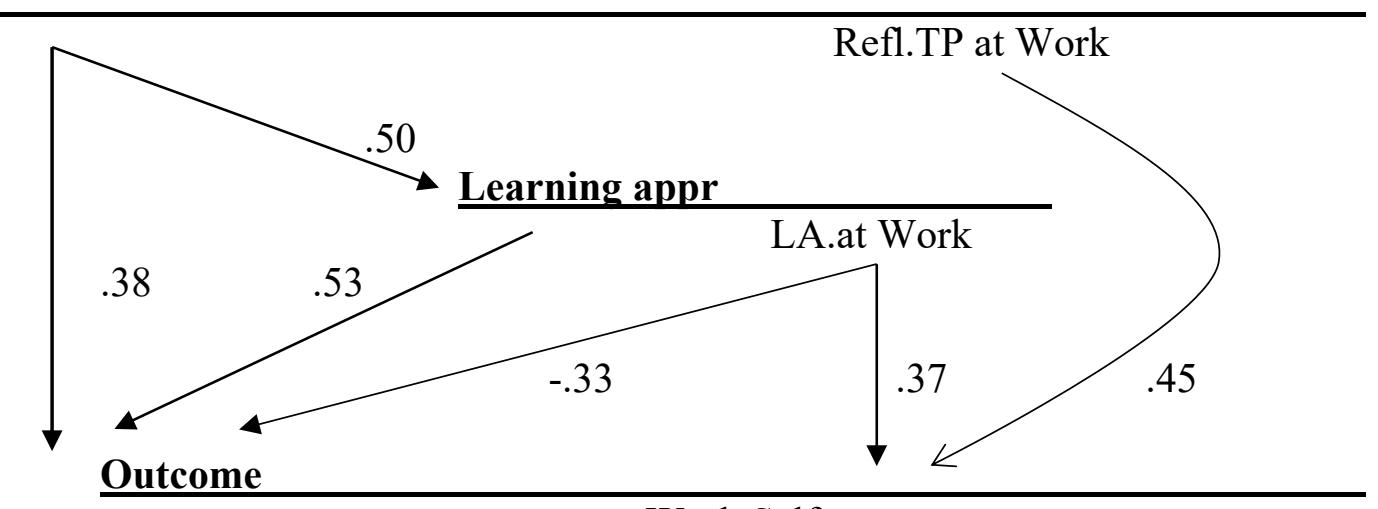

Work Self-concept

Figure 1. Structural equation modelling of the relation between factors in preschool teacher education in 2009-2011. Standardized coefficients (StdYX) for both groups. Fit indices: $\mathrm{Chi}^{2}=118,84 ; \mathrm{df}=105(\operatorname{sig} 0,17) ; \mathrm{RMSEA}=0.026 ; \mathrm{CFI}=0.984 ; \mathrm{SRMR}=0,053$. General factors above lines in bold, specific factors under lines (see Tables 1-3).

3 This reference is to Eleanor Gibson, involved in establishing ecological psychology on the fundamentals of the theory about affordance made by her husband, James Gibson. 


\section{Invitation to reflection}

Among the needed skills for taking advantage of affordances are repertoires of reflection, which have a prominent place in teacher education, as discussed above. However, using theory for reflection means seeing affordances from another perspective than what the human mind ordinarily does (Withagen et al., 2017, p.12). Reflection together with campus teachers, mentors, and staff at workplaces, where practicum is taking place, is therefore a demanding task.

The questionnaire items investigated whether students had had invitations to take part in such processes (Table 1). In the measure of reflection on theory and practice (TP), the general factor concerns campus courses (Refl.TP), and the specific factor is about the workplace or practicum (Refl.TP at Work). The constructs make references to campus teachers, to the school staff and the supervisor, and to tutoring, and are thereby alluding to boundary crossing together with these people. The questionnaire asks whether the teacher education teachers, tutors, and school staff make students aware of theoretical implications that are possible to see among affordances. 


\begin{tabular}{lccc}
\hline \multicolumn{1}{c}{ Reflection on theory-practice } & ReflTP & ReflTP at W & Res \\
$\begin{array}{l}\text { 2g. With the content of the courses as a base, we have } \\
\text { been able to practice preschool teachers' working } \\
\text { methods. }\end{array}$ & .726 & .473 \\
$\begin{array}{l}\text { 2h. Course content was intended to highlight practical } \\
\text { problems at work. }\end{array}$ & .592 & .553 \\
$\begin{array}{l}\text { 2j. The teachers seem to have a clear picture of the } \\
\text { theory-practice relation in education }\end{array}$ & .558 & .689 \\
$\begin{array}{l}\text { 4d. My supervisor would like to include theoretical } \\
\text { arguments when we discuss } \\
\text { practical tasks. }\end{array}$ & .209 & .642 & .544 \\
$\begin{array}{l}\text { 4i. The staff here are interested in discussing the link } \\
\text { between practice and theory. }\end{array}$ & .233 & .783 & .333 \\
$\begin{array}{l}\text { 4j. The tutoring has encouraged me to become more } \\
\text { aware of my own learning at work. }\end{array}$ & .196 & .800 & .323 \\
$\begin{array}{l}\text { 4o. There are many here who are positively self- } \\
\text { critical and reflect on the content of the work. }\end{array}$ & .242 & .544 & .645 \\
\hline
\end{tabular}

Table 1. Campus-and practicum-based reflection on theory and practice (ReflTP). Specific factor: Reflection at practicum (ReflTP at W). Stand. solution (StdYX) in Mplus5. Res = residuals. Fit indices: $\mathrm{RMSEA}=0.028$; Chi2 $=11,495, \mathrm{df}=10(\mathrm{p}=0,32)$; $\mathrm{CFI}=0.996$; $\mathrm{SMRM}=0,028$. Initial questions: 2. How have you felt during the courses? 4. Think about your field-based education sites and how tasks related to how the educational training worked there.

\begin{tabular}{|c|c|c|c|}
\hline Study and learning patterns & Lappr & Lappr at Work & Res \\
\hline $\begin{array}{l}\text { 3b. I don't accept anything I've read without first } \\
\text { carefully thinking it through. }\end{array}$ & .562 & & .684 \\
\hline $\begin{array}{l}3 \mathrm{~d} \text {. I'm really going to find the points in what I'm } \\
\text { reading. }\end{array}$ & .682 & & .535 \\
\hline $\begin{array}{l}\text { 3f. I try to see connections between what we read and } \\
\text { situations outside the course. }\end{array}$ & .608 & & .631 \\
\hline $\begin{array}{l}5 \mathrm{c} \text {. When I learn a new task, I like to imagine and } \\
\text { think about the consequences of different ways of } \\
\text { doing it. }\end{array}$ & .519 & .456 & .523 \\
\hline $\begin{array}{l}\text { 5d. I am always interested in examining how different } \\
\text { work-related tasks function together. }\end{array}$ & .486 & .544 & .468 \\
\hline $\begin{array}{l}\text { 5e. When I try something new at work, I turn the } \\
\text { arguments over in my mind because it is important. }\end{array}$ & .614 & .442 & .427 \\
\hline
\end{tabular}

Table 2. Study and learning approaches (Lappr). Specific factor: Workplace learning approach (Lappr at Work). Stand. solution (StdYX) in Mplus5. Res = residuals. Fit indices: RMSEA =0,030; $\mathrm{Chi}^{2}=10,53, \mathrm{df}=9(\mathrm{p}=0,31) ; \mathrm{CFI}=0,996 ; \mathrm{SMRM}=0,026$. Initial questions: 3 . Think about how you currently work with the literature and course assignments, respectively. 5 . Think about how you now obtain practical information in the field-based education.

\section{Deep and surface learning approaches}

To perceive theoretical possibilities for interpretation, students themselves have to grasp the learning task in a 'deep' way. Deep learning (Marton, 1983) approaches (Table 2) are thus included as mediating factors in the model. The general factor is dominated by items about such a deep study approach, formulated in order to operationalise Marton's (1983) concept. We alternately call this the general learning approach (Lappr), or the study approach. By 'deep' we mean engagement to seek meaning in a task, which is a supposition for reflection. The specific factor is an attempt to measure similar phenomena in working life (Lappr at Work), rather than relating them to reading literature as in Marton's case (Lander, 1996). We call 
the factor the learning approach at work. According to our theory for the model analysed here, practice aspects of both campus and workplace education get their own hypothesised mediating factor, and the hope is to see them in cooperation.

Approaches are seen as focused ( $\mathrm{q} 3 \mathrm{~d}, \mathrm{q} 5 \mathrm{~d})$ ), critical ( $\mathrm{q} 3 \mathrm{~b}, \mathrm{q} 5 \mathrm{e})$, and associative (q3f, q5c), which are aspects mentioned by Marton (1983) (op. cit.), and operationalised in Lander (1996). They are not cognitive schemas or representations, but exploratory activity functions to handle learning problems. For the so-called ecological psychology, it is important to address the development of thinking as behaviour, ${ }^{4}$ not as cognition (Gibson, 2003b). But of course, reflection upon theory and practice aims at connecting bodily perception to conceptual thinking. When Gibson (2003a, p. 286) describes learning from affordance as a more and more economic selection of useful information, we should remember that a basic idea of theory is to increase that economic efficiency.

Marton (1983) also describes a surface approach, by which students fail to explore and instead turn to root learning. He also claimed that the choice of approach is caused by situational demands. Nevertheless, Biggs (1987) argued that this explanation is truer for surface than for deep approaches, as the latter tend to be learned as valid over time by students. We do not think that a certain measure of surface approach is vital to our understanding of how affordance meets reflection. We acknowledge that deep approaches may reflect both individual and contextual influences.

\section{Outcomes}

Outcomes (Table 3) have the intellectual and learning stimulation from courses as a general factor (Out), and the specific one deals with self-concept in managing the work as a preschool teacher (WorkSC). The specific self-concept is a version of the academic self-concept (Marsh, Walker, \& Debus, 1991), but it refers to learning at work instead of referring to an academic subject. The format has earlier been tested for a measure of health self-concept (Lander, 2002). Self-concept is seen as the ultimate outcome of the education. It is a complement, or competitor, to Bandura's (1997) concept of self-efficacy, which is much more detailed in measurement and deals with more specific areas of achievement. However, it has been shown that both have predictive value. While self-efficacy seems to be a better predictor of actual achievement in an area, self-concept seems to be a better predictor of interest and emotional involvement for the same area (Ferla, Cai, \& Valcke, 2006). We can, thus, interpret it as a motivational factor (Ford, 1992), making adjustment to the new situation as a preschool teacher possible in that respect.

\begin{tabular}{|c|c|c|}
\hline Education outcomes & Work SC & Res \\
\hline $\begin{array}{l}2 \mathrm{i} \text {. The content of the courses has been intellectually } \\
\text { stimulating. }\end{array}$ & .644 & .586 \\
\hline $\begin{array}{l}2 \mathrm{u} \text {. I feel that I developed through my learning in the } \\
\text { courses. }\end{array}$ & .835 & .302 \\
\hline
\end{tabular}

\footnotetext{
${ }^{4}$ The Gibsonian view on behavioral psychology does not conform to Watsonian behaviorism.
} 
4n. I find it easy to understand how new tasks can performed in the preschool profession.

Table 3. Outcomes of the Education (Out). Specific factor: Self-concept in relation to practice (WorkSC). Stand. solution (StdYX) in Mplus5. Res = residuals. Fit indices: RMSEA =0,000; Chi2 $=0,17, \mathrm{df}=1(\mathrm{p}=0,68) ; \mathrm{CFI}=1,00 ; \mathrm{SMRM}=0,006$. Initial questions, see Tables 1 and 2 .

The impact that reflection has upon theory and practice in a stimulated ego and its impact on the working self-concept, mediated through learning approaches, is thus the reconstructed programme theory to be tested here on two different variants of a preschool teacher education.

\section{Methods}

\section{Investigated groups}

The method is a questionnaire handed to 193 Swedish students at the end of their studies on a university programme for preschool teachers. Eighty-eight students with a nursery nurse ${ }^{5}$ background completed their questionnaires in autumn 2009 , and spring 2011; we call them the nurse group. Students from four semesters of the regular preschool teacher education programme (105 students) took part between autumn 2009 and spring 2011. They are here called the campus group. Questionnaires were administered by the students' teachers during lectures, on our behalf.

Nurses who previously worked in preschools were recruited to the preschool teacher education partly because of a lack of preschool teachers holding degrees, a problem that over time has grown bigger. These nurses in Sweden work mostly with children in preschools. Leading play, care, and other pedagogical activities is a large part of their work. They develop the pedagogical activities together with the preschool teachers, but the latter have the overall pedagogical responsibility. Students with a nurse background already had an upper-secondary education for that profession and had been recruited to the programme by getting credits for their previous work in preschools (on average 11.2 years $^{6}$ ). The group of nurses spent four days a week at their workplace and one day on campus. Their field-based education was arranged as workplace learning. The basic idea was that their local workplace would afford authentic learning situations in order to integrate theory and practice. It was planned that they should work at their workplaces while carrying out their university assignments at the same time.

\footnotetext{
${ }^{5}$ These students have a background as nursery nurses in preschool. See an English translation in Cambridge dictionary and Whitters (2018). In Swedish preschools, they are called barnskötare and we have chosen to call them the nurse students or nurse group in this article.

${ }^{6}$ Questionnaire item: Have you worked at some preschool before this education? (Yes/No). If Yes for how long (either full time or part time)? .... years.
} 
Students participating in the traditional campus- and field-based university education approach, that is, the campus group, first explored theory on campus and then went out into field-based education to implement their knowledge and put theory into practice, so to say. They had an average of 1.5 years of experience from work in preschool, but about half of them had no such previous experience at all.

In total, students in the campus group had 20 weeks of field-based education (practice) during their 3.5-year teacher education programme. By giving them credit for their previous work, the programme in which the nurse group took part was shortened to three years. Both groups had a common syllabus, course literature, and examinations, and were taught by the same teachers on campus, although they did not belong to the same classes. During the field-based education, each student had a supervisor from the local preschool. The campus students had mentors who had undergone a short training course in tutoring while the nurses' mentors lacked this specific training.

The response rate for the campus group was $78 \%$ and for the group of nurses $80 \%$. The internal drop-out was very low and modelled by the EM-method (expectation-maximisation) before data were used in analysis.

\section{Structural equation modelling and multiple regression}

Analyses were done with structural equation modelling (SEM) with Mplus5, and the use of the pre-processor STREAMS (Gustafsson \& Stahl, 2000) for the whole group. We supplemented this with multiple regression path analysis (IBM-SPSS 24) to gain a better ratio between numbers of participants $(N)$ and number of parameters when we dealt with the two subgroups. Such ratios are much debated (see e.g., Iacobucci, 2010; Ullman, 2006). According to the Department of Statistics and Data Sciences $(2015$, p. 8) five cases per parameter estimate should be enough in SEM when data are perfectly 'well-behaved' (normally distributed, no missing data or outliers).

The SEM-analysis has 3.98 individuals per parameter in measurement and structural models together. This is because it uses nested models, which are costly in the number of relations, as some items have more than one relation. For multiple regression, the tutorial states that about 200 individuals are required, but also that ' 15 cases per predictor is a good general rule' and 'not unreasonable' (Department of Statistics and Data Sciences, 2015, p. 8) also in SEM. We have five predictors when the regression models are the greatest, which results in 17.6 individuals for the nurse group, and 21 for the campus group.

Plots for standardised residuals and fitted values were checked together with linearity of relations, normal probability plots, and collinearity. There were no multivariate outliers (Mahalanobis $\mathrm{D}^{2}$ ). Latent factors in SEM got their scales by fixing one of their dependent variables to 1 . Data seem to be rather 'well-behaved' and therefore it came as no surprise that an SEM-analysis with the robust MLM estimation method (adjusting for non-normality) did not change the results in any particular way from the one done with the default ML-estimator. 
Fit indices for SEM were within reasonable limits (see Figure 1 and Table 1). A weakness, however, is that the number of items in two measures (outcomes and working self-concept, see Table 4) for the multiple regression were too few and therefore had low reliability. As part of a nested model, however, they worked well. We are confident that our analyses are reliable and valid, as the two methods show a very high similarity in results.

\begin{tabular}{lllllll}
\hline & $\begin{array}{l}\text { Reflection } \\
\text { theory-practice at } \\
\text { campus }\end{array}$ & $\begin{array}{l}\text { Refl. TP at } \\
\text { work }\end{array}$ & $\begin{array}{l}\text { Study } \\
\text { appr. at } \\
\text { campus }\end{array}$ & $\begin{array}{l}\text { Learn. appr. } \\
\text { at work-place }\end{array}$ & $\begin{array}{l}\text { Out- } \\
\text { come }\end{array}$ & $\begin{array}{l}\text { Work } \\
\text { self } \\
\text { concept }\end{array}$ \\
$\mathrm{M}$ & 4,02 & 3,39 & 3,89 & 3,82 & 4,44 & 3,91 \\
$\mathrm{~s}$ & 0,50 & 0,80 & 0,56 & 0,64 & 0,58 & 0,62 \\
$\alpha$ & 0,71 & 0,82 & 0,70 & 0,76 & 0,69 & 0,60 \\
$\%$ pos N. & 92 & 44 & 85 & 69 & 99 & 91 \\
$\% \operatorname{pos~C}$ & 83 & 50 & 79 & 73 & 94 & 81 \\
\hline
\end{tabular}

Table 4. Means and standard deviations for the whole group of students, and percent positive in subgroups. Means (M), standard deviations (s) and Cronbach's alpha $(\alpha)$ for factors used in multiple regression analyses, plus per cent with positive attitudes $(>3,45)$ among nurse students $(\mathrm{N})$ and regular students $(\mathrm{C})$.

Our data do not come from a random sample. We therefore consider our models to be at what Berk (2010) called a descriptive level 1-analysis, which does not aspire to make generalisations for a population or to make causal claims other than tentative ones. This was a case-study and the models investigate some aspects of a programme theory for that case.

\section{Measures in nested models}

Table 1 gives details of the nested models in use. ${ }^{7}$ The questionnaire used five-point Likert scales (Are these claims appropriate for you? Responses from not at all to highly). An earlier explorative factor analysis was done by principal axis extraction (oblique rotation, Direct Oblimin, in IBM SPSS 24; Lander, 2012). Based on this and theoretical considerations, factors were chosen to be tested by Cronbach's alfa (Table 5) and by confirmatory factor analyses (Table 1).

\begin{tabular}{|c|c|c|c|c|c|}
\hline Dep $\downarrow /$ Indep $\rightarrow$ & Refl.TP & $\begin{array}{l}\text { Refl. TP at } \\
\text { Work }\end{array}$ & Learn. appr & $\begin{array}{l}\text { LA at } \\
\text { Work }\end{array}$ & Outcome \\
\hline \multicolumn{6}{|l|}{ SEM. Total group } \\
\hline Outcome & .65 & - & .52 & -.33 & $\mathrm{x}$ \\
\hline Work Self-concept & - & .45 & - & .37 & $\mathrm{x}$ \\
\hline \multicolumn{6}{|c|}{ Mult. regr. Total group } \\
\hline Outcome & .58 & - & .28 & - & $\mathrm{x}$ \\
\hline Work Self-concept & .17 & .33 & .12 & .22 & .16 \\
\hline Dep $\downarrow /$ Indep $\rightarrow$ & Refl.TP & $\begin{array}{l}\text { Refl. TP at } \\
\text { Work }\end{array}$ & Learn. appr & $\begin{array}{l}\text { LA at } \\
\text { Work }\end{array}$ & Out /qual \\
\hline
\end{tabular}

${ }^{7}$ The multiple regression path analysis separates the learning approach for studies from the approach for work, and tests if the former influences the latter. The analysis of outcome and work self-concept is treated likewise, with the general outcome thought of as influencing the work self-concept. 


\begin{tabular}{llllll} 
N: Outcome & .51 & - & .32 & - & $\mathrm{x}$ \\
N: Work Self-concept & .15 & .23 & .42 & - & - \\
& & & & & \\
C: Outcome & .60 & - & .27 & - & $\mathrm{x}$ \\
C: Work Self-concept & - & .43 & - & .20 & - \\
\hline
\end{tabular}

Table 5. Total standardized effects from figure 1 (SEM), and from multiple regression for subgroups. $\mathrm{N}$ : Nurse students; C: Campus students. $(-)=$ No relations, or with coefficients $<0,10$, and excluded. $\mathrm{x}=$ Not adequate.

All factors in SEM were made up as nested models to improve specificity. A nested model has a general factor that aggregates variation from all indicators (items), but some indicators are also connected to one or more specific factors. The indicators which are only tied to the general factor to a high extent determine what kind of variation this factor draws from indicators also belonging to the specific factors. The specific factor thus becomes purer, as variations that are common with other items are withdrawn. This is shown more technically in Tables 1-3. We now present our measures and results more in depth.

\section{Results and interpretations}

In Table 4, means and standard deviations for the whole group of students, and percent positive in subgroups, are shown for each of the factors. The outcome of the programme is acknowledged by almost all. General measures heavily related to the campus education have positive opinions (i.e., grade 4 or 5 on the scales) of about 80-90 per cent (Reflection theory-practice; study approach). On the other hand, when going down to $80 \%$, it means that one fifth of the students are not very satisfied.

The analysis is presented through two themes. The first theme is campus, workplace, and reflection, where both student groups are analysed together. The second theme presents a subgroup analysis linked to the theory-practice complex.

\section{Campus, workplace, and reflection}

Reflection about theory and practice at the workplace was only recognised by 44 or 50 per cent of the students, and the learning approach at the workplace was claimed to be used deeply by about 70 per cent. The item (q4d) about the mentors' interest in taking up theory when discussing practical tasks for the first factor was especially low in both groups ( $1 / 3$ pos.), but the same number of nursing students thought that staff (q4i) were interested in such matters (while $44 \%$ of campus students did). The other two items ( $\mathrm{q} 4 \mathrm{j}, \mathrm{q} 4 \mathrm{o})$ showed positive opinions for 44-56 per cent. The ambition of cross-fertilisation between theory and practice in situ was thus sustained for only about half the students.

Similar messages from all analyses about a practice-theory cleavage

The SEM results for the whole group of students are shown in Figure 1. Table 5 shows total effect data from both Figure 1 and a parallel analysis of subgroup data 
by multiple regression. Results in the two models seem remarkably alike, with one exception: The SEM analysis shows a negative relation of some magnitude between learning approach at work and outcome. In the multiple regression models, a very small negative relation, far from significant, first showed up, but was taken away. A similar result was shown in the MLM model tried, that is, a nonsignificant small negative coefficient. If we accept this negative sign, it can be interpreted that those students claiming a deeper learning approach at work were somewhat more negative towards the outcome, that is, the overall quality of the programme. It may represent a critical understanding of missed opportunities on behalf of the programme.

The results, however, give us some reassurance that the relatively low number of individuals for the SEM analysis is not a big problem here. In the SEM model in Figure 1, there is a very obvious division between the campus and the workplace content and experiences. Working self-concept is only related to what happens at the workplace in terms of both reflection and learning approach. The outcomes of the programme in terms of stimulation and learning from courses are only related to the campus experiences, except for the negative influence of learning approach at the workplace that was noticed.

In the upper section of Table 5, total effects for both outcomes and the total groups are calculated with a threshold of at least $\geq 0.10$. The theory-practice cleavage is clear in both analyses: reflection on campus concerns mostly intellectual stimulation and course learning; reflection at workplaces concerns mostly working self-concept.

\section{Campus and workplace - two different reflection environments}

The two kinds of reflection environments in the programme thus merge very little. The models assume that this happens in two ways, either directly or by mediation from learning approaches. Figure 1 (and the parallel multiple regressions) shows mediating effects, but relatively weak ones. For SEM, they show the same pattern as above: learning study approaches 'only mediate' stimulation and course learning as outcome. Learning approaches at work mediate positively only to self-concept at work, and negatively to other outcomes (Figure 1). However, no kind of learning approach relates to theory-practice reflection at work, only to such reflection on campus.

\section{Subgroup analyses}

In a subgroup analysis (Table 5) we noticed that the theory-practice complex at the workplace seems to have had a bigger impact on the campus students than on students who were nurses. Reflection upon this at the workplace affects the working self-concept of both groups, but twice as much among the campus students. A deep learning approach at work affects only the campus students' working self-concept. 
Campus students thus seem to have had more effective work discussions and learning approaches at work in terms of affecting their self-concept for preschool teacher work. Campus students are most likely relying on their participation in an internship that can be described as a community of practice (Wenger, 1998) or learning environment in preschool, but as activities at work are new things for most of them, they probably feel more affected by them. We can imagine that they are more active agents in affordance processes at work, eager to learn about a new environment. At the same time, this may hamper the influence from general learning approaches compared to the nurses' experiences. Campus students, with relatively little work-experience at preschools, need to get both the study approach right and then the learning approach at work right, to incorporate the campus content of reflection into their self-concept for the new job, and the latter relation is therefore missing in Table 5.

\section{Nurses without deep learning approaches at workplaces}

The nurses' working self-concept is only affected by reflection on theory-practice at work (to some extent), and not by deep learning approaches at work. Instead, what is happening on campus, in terms of reflection and deep learning approaches, is more influential for their working self-concept. As they have turned away from an earlier chosen nursing profession, of which they have much or a good deal of experience, to a new profession, their activity in affordance processes is relatively more challenged by what is happening on campus and that demands learning approaches for studies.

However, reflection at the workplace is not without influence on their working self-concept when it takes place. But learning approaches at work do not influence their working self-concept. We may think that they are already engaged in discussions at the workplaces, mostly as nurses, and not so much as preschool teachers-to-be, and therefore their deep learning approaches at work concern nursing tasks. They may experience a dilemma in attempting to become peripheral participants in preschool teacher communities and at the same time meeting expectations from their colleagues about the job as usual. These expectations and discussions seem seldom to actualise deep learning approaches at work connected to theorising. The nurses seem to undergo restructuring efforts, as the learning from texts and seminars is taken into the self-concept for work, but that is not being mediated by deep learning approaches at work.

We may thus speculate that nurses, through their habits when among colleagues, already had functioning and institutionalised learning approaches at work for daily problem-solving, which are not so easily changed to be a new part of the working self-concept. Campus students are not hesitating in this regard because their self-concept is newer, and not in need of restructuring, the way the nurses' self-concept is. Campus students seem to be managing deep learning of two kinds at the same time for the benefit of their new self-concepts, while the nurses' problems are about restructuring their self-concepts directly from study approaches, without the help of related learning approaches at work. 


\section{Student outcomes and deep learning approaches}

We may also ask about the relatively low outcome as intellectual stimulation and learning. The message is that you can be content with your education without using deeper learning approaches but that it is better if you also use the latter assumed for studying (but might be hampered by using a deep learning approach for work). Calculating this with the help of the parallel multiple regression model, the role of influence coming from reflection on campus (Refl. TP) directly is 81 per cent and from the study approach mediation consequently 19 per cent.

Making the same calculations for subgroups, the direct effect for the nurses is 78 per cent, and for campus students 82 per cent. The nurses may have struggled more, needing a deeper study approach, having to do with texts and seminars, than campus students did, but the main message for all is about low mediation from learning approaches concerning the stimulation and learning on courses. Given that the measures of deep approaches of both kinds are valid, this may also show us that course demands have not been adequate for a great many students.

\section{Discussion}

The aim of this study was to investigate how preschool teacher education students within two different educational models and learning environments are afforded opportunities of learning and reflection in relation to the theory-practice complex. While most students in the study were satisfied with aspects of their education, only around half of the group acknowledged the way theory-practice reflection was treated at workplaces during practicum. Interpretations of SEM and multiple regression analyses of student responses could easily show a clear division into what was done mostly related to campus and mostly related to workplaces.

Analyses thus provide support for seeing campus education and workplace education as bearers of two different fields of affordances over theory-practice reflections, which is also in line with Rietveld and Kiverstein's (2014) argument. Reflections upon theory and practice in these two educational environments had different consequences: outcomes such as stimulated intellectual development and learning were connected to campus reflection, and self-concept for work was connected primarily to workplace reflection. Learning approaches of two kindsfor study and for work - were thought to mediate reflection in the two educational environments as well as the outcome and self-concept.

Mediation was present in the case of outcomes of stimulation and learning, but to a lesser extent than expected and perhaps in a more negative way between the learning approach at work and outcomes, possibly mostly concerning nurses. The general learning approach, mostly connected to campus, had a mediating function for the nurses' working self-concept, but for campus students this mediation also went through their learning approach at work.

This can be interpreted as two different types of affordance that campus students and the students who were nurses are facing. Campus students had to deal 
with both learning approaches for study and for work, in order to take advantage of campus reflection for their self-concept. The nurses tried to use study approaches directly for restructuring their self-concepts and did not seem to be helped by learning approaches for work. An explanation for these two types of affordance would be that the knowledge production and learning processes are structured and organised differently in campus and field-based education, and that the campus students and the group who were nurses handle this situation in two different ways (Billett, 2011; Costley \& Armsby, 2007).

For their self-concepts, both groups were dependent on discussions (about theory and practice) at the workplaces, but campus students twice as much so than the nurses. Workplace discussions were not helpful in using deep learning approaches at work for either group; nor did they stimulate general learning approaches for study. We think that collective affordances in workplaces were mostly related to matters of daily problem solving, and not related to trying to adjust established repertoires for this with the help of theory. In a way, we think that this became a void for campus students, and affordance blocking for nursing students, in their attempts to build a new self-object, or to restructure their self-objects, to suit the preschool teacher roles.

In an earlier version of this analysis, we used four items for measuring attitudes toward the examination, both in terms of academic and practical tasks. We took that factor away as it turned out to be a dead end. It did not relate to theorypractice discussions at work or to either of the two learning approaches, but only to discussions on campus. It did not affect intellectual outcomes or self-objects. Thus, it would not improve our model. However, it reveals a missed opportunity in the programme theory that we investigated, as exams are known to have an impact on educational processes and results.

In this case, only campus teachers constructed examination tasks with no input from workplace mentors. By relating only to campus discussions, the examination contributed to the dichotomy between theory and practice, which is what Garraway (2010) predicts.

We can see (at least) one weakness in the analysis. The measures of theorypractice discussions in the two arenas may implicitly also cover other aspects, as there are no other measures of them. Questionnaire items are about reflection, but also about who takes part and about course content, supervisor behaviour, and so on. This may blur the results a bit, but it does not undermine the main conclusions.

\section{Conclusions}

The analysis shows that the two educational environments, the campus and fieldbased education (workplace) afford two different ways of reflecting on theory and practice, which both student groups must adhere to. The analysis also shows that there are differences between campus students and those who were formerly nurses in the way they relate to the affordances from the educational environments, and this is probably based on their educational background and experiences. This 
observation is important and has rarely been the subject of discussion or reflection regarding this form of teacher education in Sweden.

Although the study's empirical material is from the years 2009-2011, the study's focus and analysis are highly relevant. The discussion about reforming and strengthening teacher education is constant and ongoing in Sweden ${ }^{8}$. Both Bronäs and Selander (2015) and Karlsson Lohmander (2015) point out that teacher education is too theoretical and that the connection between theory and practice must be strengthened. Likewise, more and more teacher education programmes today organise their activities through various hybrid models and practice schools. We think that our measures and design may contribute to the evaluation of such models.

The analysis is in line with both Rietveld and Kiverstein (2014) and Withagen et al. (2017) who pointed out that how the students receive the environment's affordance depends on skills and knowledge that they have acquired before and during their teacher education. It is this knowledge and experience that makes the two student groups relate differently to the affordance they receive from campus studies and workplaces as educational environments.

What implications should this analysis have for preschool teacher education in Sweden? Our analysis shows that neither of the two models was in line with earlier policy intentions (SOU 1999: 63). The programme did not become the kind of 'hybrid' teacher education that Eriksson (2009) and Lenz Taguchi (2010) sought. It looks like the programme that was investigated relied too much on the individual student's reflection as the solution to the transfer problem, which Zeichner (2007) also claims is dangerous. This reliance seemed to work somewhat better for campus students, who were more challenged by the (for them) new environment in practice, and its affordances. The students within the field-based education are very close to the preschools' pedagogical micro-practice, which especially for students who are nurses, limits the possibility of a critical reflection on theory and practice and its contextual conditions. We interpreted our findings as indicting that workplace routines and norms structure the students' learning and professional knowledge instead (Billett, 2011). For both groups, but especially for nursing students, the boundary zones evolving between theory on campus and practice at the workplaces were too weak and fragmented. It ought to be further investigated if the training of campus students' mentors had a different impact on the groups, but our result does not point to that. Still, a better-organised boundary zone must build on 'expansive learning' (Engeström \& Sannino, 2010), that is, students, campus teachers, and mentors need collectively to be engaged in constructing and implementing more hybrid forms of education which allow more horizontal learning (Gutiérrez, 2008). It also seems important to have new forms of examinations that contribute to a deep learning approach.

\footnotetext{
${ }^{8}$ Reform of teacher education. Retrieved 19 October 2020 from https://www.regeringen.se/pressmeddelanden/2019/10/reformering-av-lararutbildningen/
} 


\section{Author biographies}

Jan Gustafsson Nyckel holds is a $\mathrm{PhD}$ in Education and Professor in Educational Sciences at University West. He is a fellow in the research milieu Childhood and Youth studies and leader for the research group Education, Policy and Agency. His main research interest is in policy studies in preschools, school-age education, and care, compulsory schools and teacher education. He often uses ethnographic and discourse analytical methods and theories in sociology of education and policy assemblage.

Rolf Lander is a $\mathrm{PhD}$ and Senior Professor in Education, Faculty of Education, University of Gothenburg. His main interests concern research in school development, organisation and evaluation, and also taking part in mentoring in higher education.

Per-Olof Thaing is an educated psychologist and $\mathrm{PhD}$ in Education. He is Senior Professor in Education, Faculty of Education, University of Gothenburg, and former Dean for the Faculty. Main research interests are adults' learning and vocational education and training. He was Director for Centre for vocational knowledge and skills, University of Gothenburg, and Chief Editor for Nordic Journal for Vocational Education and Training. 


\section{References}

Akkerman, F. S., \& Bakker, A. (2011). Boundary crossing and boundary objects. Review of Educational Research, 81(2), 132-16.

Allen, J. M., \& Wright, S. W. (2014). Integrating theory and practice in the preservice teacher education practicum. Teachers and Teaching: theory and practice, 20(2), 136-151. DOI: 10.1080/13540602.2013.848568

Astbury, B., \& Leeuw, F. L. (2010). Unpacking black boxes: Mechanisms and theory building in evaluation. American Journal of Evaluation, 31(3), 363381.

Bandura, A. (1997). Self-efficacy: The exercise of control. New York: W.H. Freeman.

Beach, D. (2000). Continuing problems of teacher education reform. Scandinavian Journal of Educational Research, 44(3), 275-291.

Beavers, E., Orange, A., \& Kirkwood, D. (2017). Fostering critical and reflective thinking in an authentic learning situation. Journal of Early Childhood Teacher Education, 38(1), 3-18.

Bell, N. (2004). Field-based teacher education at multiple sites: A story of possibilities and tensions. Research \& Policy Series No. 2. Wellington, New Zealand: Institute for Early Childhood Studies, Victoria University of Wellington.

Berglund, E., Gustafsson, J., Lager, K., \& Lundqvist, J. (2019). Det dubbla kompetenskravet: En studie av lärarstudenters kompetenslärande inom en ny lärarutbildning. Forskning i paedagogers profession og uddannelse, 3(1), 88101.

Berk, R. (2010). What you can and can't properly do with regression. Journal of Quantitative Criminology, 26(4), 481-487.

Biggs, J. B. (1987). Student approaches to learning and studying. Melbourne: Australian Council for Educational Research.

Billett, S. (2001). Learning through work: workplace affordances and individual engagement. Journal of Workplace Learning, 13(5), 209-14.

Billett, S. (2011). Workplace curriculum: Practice and propositions. In F. Dochy, D. Gijbels, M. Segers, \& P. Van den Bossche (Eds.), Theories of learning for the workplace (pp. 17-36). London: Routledge.

Bronäs, A., \& Selander, S. (Eds.) (2015). Verklighet, verklighet: teori och praktik $i$ lärarutbildning. ( $2^{\text {nd }}$ ed.). Lund: Studentlitteratur.

Costley, C., \& Armsby, P. (2007). Work-based learning assessed as a field or a mode of study. Assessment \& Evaluation in Higher Education, 32(1), 21-33.

The Department of Statistics and Data Sciences (2015). Structural Equation Modeling Using AMOS. An Introduction. Statistical Data Sciences. Statistical Consulting. The University of Texas at Austin. 
Dewey, J. (1904). The relation of theory to practice in education. In C. A. McMurry (Ed.), The Third Yearbook of the National Society for the Scientific Study of Education. Part I. (pp. 9-30). Chicago, IL: The University of Chicago Press. Dewey, J. (1988). Experience and education. West Lafayette Ind: Kappa Delta Pi. Engeström, Y., \& Sannino, A. (2010). Studies of expansive learning: Foundations, findings and future challenges. Educational Research Review, 5(1), 1-24.

Englund, T. (1996). Didaktik på läroplansteoretisk grund. I Karsten Schnack red: Laeseplansstudier 3. Didaktiske studier. Bidrag til didaktikkens teori og historie. Danmarks Laererhöjskole, s 439-466.

Eriksson, A. (2009). Om teori och praktik i lärarutbildning. En etnografisk och diskursanalytisk studie. Göteborg: Acta Universitatis Gothoburgensis.

Erlandsson, P. (2007). Docile bodies and imaginary minds: on Schön's reflection in action. (Diss). Göteborg: Acta Universitatis Gothoburgensis.

Ferla, J., Cai, Y., \& Valcke, M. (2006). Academic self-efficacy and academic selfconcept: Reconsidering structural relationships. Learning and Individual Differences, 19(4), 499-505.

Ford, M. E. (1992). Motivating humans: Goals, emotions, and personal agency beliefs. Newbury Park, CA: Sage.

Franke, A., \& Dahlgren, L. O. (1996). Conceptions of mentoring: An empirical study of conceptions of mentoring during the school-based teacher education. Teaching and Teacher Education, 12(6), 627-641.

Garraway, J. (2010). Knowledge boundaries and boundary-crossing in the design of work-responsive university curricula. Teaching in Higher Education, 15(2), 211-222.

Gibson, E. J. (2003a). The world is so full of a number of things: On specification and perceptual learning. Ecological Psychology, 15(4), 283-287.

Gibson, E. J. (2003b). What psychology is about: Ruminations of an opinionated aged psychologist. Ecological Psychology, 15(4), 289-295.

Gustafsson, J.-E., \& Stahl, P. A. (2000). STREAMS User's guide. Version 2.5 for Windows. Mölndal: MultivariateWare.

Gutiérrez, D. K. (2008). Developing a sociocritical literacy in the third space. Reading Research Quarterly, 43(2), 148-164.

Han, S., Blank, J., \& Berson, R. I. (2017). To transform or to reproduce: Critical examination of teacher inquiry within early childhood teacher preparation, Journal of Early Childhood Teacher Education, 38(4), 308-325.

Iacobucci, D. (2010). Structural equations modeling: Fit Indices, sample size, and advanced topics. Journal of Consumer Psychology, 20(1), 90-98.

Karlsson Lohmander, M. (2015). Bridging 'the gap' - linking workplace-based and university-based learning in preschool teacher education in Sweden. Early Years, 35(2), 168-183.

Kim, K., \& Kim, J. (2017). Going beyond the gap between theory and practice: Rethinking teacher reflection with poststructural insights. Journal of Early Childhood Teacher Education, 38(4), 289-303. 
Klien, E., Taylor, M., Onore, C., Strom, K., \& Abrams, L. (2013). Finding a third space in teacher education: creating an urban teacher residency. Teaching Education, 24(1), 127-57.

Korthagen, F. A. J. (2010). The relationship between theory and practice in teacher education. In P.L, Peterson, E.L; Baker, \& B. McGaw (Eds.), International Encyclopedia of Education ( $3^{\text {rd }}$ ed.) (pp. 669-675). Oxford: Elsevier.

Lander, R. (1996). Djupa och ytliga studiemönster. Elevernas förhållningssätt till studieuppgifter som kvalitetsindikatorer. Pedagogisk forskning i Sverige, 1(4), 211-229.

Lander, R. (1998). Fyra program på Vårdhögskolan i Göteborg 1995 - 1998. Enkätdata. Arbetsrapport från institutionen för pedagogik, Göteborgs universitet.

Lander, R. (2002). Professional cooperation around self-related measures in school indicator instruments. Journal of Classroom Interaction, 37(2), 27-36.

Lander, R. (2012). Barnskötare blir förskollärare. Enkätjämförelse med en reguljär förskollärarutbildning. Rapporter från Institutionen för pedagogik och specialpedagogik, RIPS 2. Göteborgs universitet.

Lenz Taguchi, H. (2010). Going beyond the theory/practice divide in early childhood education introducing an intra-active pedagogy. Abingdon, Oxon: Routledge.

Lundgren, H., \& Poell, R. F. (2016). On critical reflection: A review of Mezirow's theory and its operationalization. Human Resource Development Review, 15(1), 3-28.

Marsh, H. W., Walker, R., \& Debus, R. (1991). Subject-specific components of academic self-concept and self-efficacy. Contemporary Educational Psychology, 16(4), 331-345.

Marton, F. (1983). Beyond individual differences in learning. Educational Psychology, 3(2/3), 291-305.

Pawson, R., \& Tilley, N. (1997). Realistic evaluation. London: Sage.

Rietveld, E., \& Kiverstein, J. (2014). A rich landscape of affordances. Ecological Psychology, 26(4), 325-352.

Sadler, E., \& Given, L. M. (2007). Affordance theory: a framework for graduate students' information behaviour. Journal of Documentation, 63(1), 115-141.

Schön, D. A. (1983). The reflective practitioner: how professionals think in action. New York: Basic Books

Sjølie, E. (2014). The role of theory in teacher education: Reconsidered from a student teacher perspective. Journal of Curriculum Studies, 46(6), 1-22.

SOU 1999:63. (2017, February 3). Att lära och leda. En lärarutbildning för samverkan och utveckling. Stockholm: Utbildningsdepartementet. http://www.regeringen.se/rattsdokument/statens-offentligautredningar/1999/05/sou-199963/.

Swedish Council for Higher Education. (1996). Grundskollärarutbildningen 1995

- En utvärdering. Högskoleverkets rapportserie 1996:1 R. Stockholm: Högskoleverket. 
Swedish Research Council. (2015, January 15). Codex Rules and Guidelines for Research. http://codex.vr.se/en/manniska2.shtml

Ullman, J. B. (2006). Equation modelling: Reviewing the basics and moving forward. Journal of personality assessment, 87(1), 35-50.

Wenger, E. (1998). Communities of practice. Learning, meaning, and identity. New York: Cambridge University.

Whitters, H. G. (2018). Nursery nurse to early years' practitioner: role, relationships and responsibilities. London: Routledge, Taylor \& Francis.

Withagen, R., Araújo, D., \& de Poel, H. J. (2017). Inviting affordances and agency. New Ideas in Psychology, 45, 11-18.

Zeichner, K. (2007). Professional development schools in a culture of evidence and accountability. School-University Partnerships, 1(1), 9-17.

Zeichner, K. (2010). Rethinking the connection between campus courses and field experiences in college- and university-based teacher education. Journal of Teacher Education, 61(1-2), 89-99. 